\title{
Recovery experiences during vacation and their association with job stressors and health
}

\section{Experiencias de recuperación durante las vacaciones y su asociación con el estrés laboral y salud}

\author{
Pascale Hächler, Diana Pereira \& Elfering Achim \\ Department of Work and Organizational Psychology. Institute of Psychology \\ University of Bern, Suiza
}

\begin{abstract}
Vacations offer opportunities for recovery from work-related stress. However, little is known about the impact of job stressors on recovery experiences during vacation, such as psychological detachment and relaxation. This study investigated detachment and relaxation to mediate the influence of job stressors prior to vacation on recovery during vacation. A total of 136 employees from various occupations completed a questionnaire on their ability to relax and mentally detach from work during a recent vacation. Participants rated perceived time pressure and social exclusion at work prior to their vacation as well as any psychosomatic health complaints or sleep problems during vacation. The results of bootstrap mediation analysis confirmed the mediating role of recovery experiences. The association between job stressors and sleep problems was fully mediated by detachment and relaxation, whereas the association between social exclusion and psychosomatic complaints was fully mediated by relaxation. Furthermore, relaxation partially mediated the association between time pressure and psychosomatic complaints. Not only should the ability of employees to relax and mentally detach be fostered, but job stressors should be reduced in order to allow employees to reach optimal recovery during vacation.
\end{abstract}

Keywords: occupational stress; time pressure; psychosomatic complaints; detachment; relaxation

\section{Resumen}

Las vacaciones ofrecen oportunidades para recuperarse del estrés relacionado con el trabajo. Sin embargo, poco se sabe del impacto de los factores de estrés laboral en las experiencias de recuperación durante las vacaciones, como el distanciamiento psicológico y la relajación. Este estudio investigó cómo el distanciamiento y la relajación median el influjo de los factores de estrés laboral antes de las vacaciones sobre la recuperación durante las vacaciones. Un total de 136 empleados de diversas ocupaciones completaron un cuestionario sobre su capacidad para relajarse y distanciarse mentalmente del trabajo durante unas vacaciones recientes. Los participantes evaluaron la presión de tiempo percibida y la exclusión social en el trabajo antes de sus vacaciones, así como cualquier dolencia psicosomática o problemas de sueño durante las vacaciones. Los resultados del análisis de mediación usando el método bootstrap confirmaron el papel mediador de las experiencias de recuperación. La asociación entre los factores de estrés laboral y los problemas del sueño estaba totalmente mediada por el distanciamiento y la relajación, mientras que la asociación entre la exclusión social y las dolencias psicosomáticas estaba completamente mediada por la relajación. Además, la relajación medió parcialmente la asociación entre la presión de tiempo y las dolencias psicosomáticas. No sólo debe fomentarse la capacidad de los empleados para relajarse y distanciarse mentalmente del trabajo, sino que deben reducirse los factores de estrés laboral a fin de permitir que los empleados logren una recuperación óptima durante las vacaciones.

Palabras clave: estrés ocupacional, presión del tiempo, dolencias psicosomáticas, distanciamiento, relajación.

Please cite this article as: Pereira, D., Hächler, P., \& Achim, E. (2017). Recovery experiences during vacation and their association with job stressors and health. Escritos de Psicología, 10, 13-30.

Correspondencia: Diana Pereira. Department of Work and Organizational Psychology.Institute of Psychology. University of Bern, Suiza. E-mail: d.romano@bfu.ch. E-mail of coauthor Pascale Hächler: pascale.haechler@gmail.com. E-mail of coauthor Elfering Achim: achim.elfering@psy.unibe.ch 


\section{Introduction}

A growing number of Swiss employees report experiencing stress at work (Grebner, Berlowitz, Alvarado, \& Cassina, 2011) and many expect job stress to further increase in the next years (Klahr, Higton, \& Harris, 2012). This is worrisome, as a variety of job stressors have been demonstrated to negatively affect health and well-being in the long run. Meta-analytical findings indicate that this effect holds for various physical symptoms (Nixon, Mazzola, Bauer, Krueger, \& Spector, 2011), mental disorders (Stansfeld \& Candy, 2006), as well as coronary heart disease (Kivimäki et al., 2006). The issue of how to prevent the detrimental effects of job stressors, therefore, is worthy of investigation.

\section{Work and Vacation}

Sociology recognized that there has never been so much travelling during vacation as in the last century and this travelling is only in part inspired by human curiosity but to a large amount reflects the wish to temporarily escape normal working life (Krippendorf, 1987). People "in order to be able to carry on urgently need a temporary refuge from the burdens imposed by the everyday work, home and leisure" (p. xiv). Many individuals like to travel during vacation in order to recover from work stress and look for experiences during vacation that they lack during their working life. Thereby, physical displacement facilitates a detachment form work norms and rules that is a relieving experience (Korstanje, \& Busby, 2010). Thus, some theorists describe vacation as an important stabilizing factor of industrial society (MacCannell, 1976).

\section{Recovery during Vacation}

Recovery refers to a process of psychophysiological unwinding, that is, psychophysiological activation decreases to its pre-stressor level after effort expenditure at work (Geurts \& Sonnentag, 2006). As such, recovery can be seen as the opposite of the strain process (Sonnentag \& Fritz, 2007). The effort-recovery model (Meijman \& Mulder, 1998) states that individuals need a period of recuperation after a demanding workday. This allows load reactions (e.g. accelerated heart rate, fatigue) to fade and prevents prolonged activation of allostatic systems. Allostatic systems include the autonomic nervous system, the HPA axis, the metabolic system, and the immune system (McEwen, 1998). Allostatic load theory (McEwen, 1998) emphasizes the necessity of recovery to prevent a dysregulation of allostatic systems, which may manifest in poor health, including cardiovascular disease, burnout, and chronic sleep problems (Sluiter, Frings-Dresen, van der Beek, \& Meijman, 2001). This is in line with the cognitive activation theory of stress (Ursin \& Eriksen, 2004), which proposes that sustained, rather than acute, high arousal is potentially harmful to the individual's health. Recovery seems to play an important role in preventing such negative long-term effects (Geurts, 2014), and insufficient recovery is viewed as a key pathway from chronic stress to health impairments (Sluiter, de Croon, Meijman, \& Frings-Dresen, 2003). Vacations offer major opportunities for recovery to occur (de Bloom et al., 2009). A vacation is a relatively uninterrupted time off work lasting several days to several weeks (de Bloom et al., 2009; Kühnel \& Sonnentag, 2011). In a meta-analysis including seven studies published between 1986 and 2006, vacation has been shown to have beneficial effects on health with an average effect size of $d$ $=.68$, indicating a medium effect (de Bloom et al., 2009). Not taking vacations can predict poor cardiovascular health and corresponding mortality over the course of several years (Gump \& Matthews, 2000). Geurts and Sonnentag (2006) suggest two basic mechanisms through which vacations facilitate recovery: A passive and an active one. In accordance with the effort-recovery model (Meijman \& Mulder, 1998), the passive mechanism is the direct relief from demands at work and the recovery process starts as soon as no further demands are put upon the organism. The temporary alleviation of work-related duties during vacation lasts longer than on evenings or weekends and facilitates recovery. The engagement in valued activities is viewed as the active mechanism through which vacations foster recovery (de Bloom et al., 2009). This is in line with Hobfoll's (2001) conservation of resources theory, which suggests that engaging in pleasant activities of one's choice can help rebuild resources and thus prepare the individual for future challenges.

\section{Recovery Experiences during Vacation}

Sonnentag and Fritz (2007) propose psychological detachment from work, relaxation, mastery and control as important psychological processes leading to recovery. These processes are termed recovery experiences. Psychological detachment (or simply: detachment) is defined as "the individual's sense of being away from the work situation" (Etzion, Eden, \& Lapidot, 1998, p. 579), both physically and mentally. Detachment thus includes being free from work-related duties as well as not thinking about work and work-related demands or stressors. It is experienced as gaining distance from one's work and 
forgetting about the work situation (Sonnentag \& Fritz, 2007). Relaxation is characterized by low activation and positive affect. It is typically achieved through relaxation techniques or activities that do not put many demands on the individual, such as reading, taking a walk or listening to calm music (Sonnentag \& Fritz, 2007).

According to the job demands-resource-recovery model (JD-R model, Bakker \& Demerouti, 2007), especially psychological detachment and relaxation may be related to indicators of poor health, while mastery and control are expected to be more closely linked to motivational constructs such as work engagement (Kinnunen, Feldt, Siltaloppi, \& Sonnentag, 2011). Consistent with this assumption, the only study investigating all four recovery experiences during vacation found psychological detachment and relaxation to be significantly related to changes in health and well-being, while mastery and control were not (de Bloom, Geurts, \& Kompier, 2012). The current study will test psychological detachment and relaxation as predictors of health and well-being after vacation.

\section{Recovery Experiences during Vacation and Vacation effects on Health and Well-Being}

In a study examining both detachment and relaxation during vacation, detachment was correlated to health and well-being during and after vacation as well (de Bloom et al., 2012). In regression analysis, detachment during vacation significantly predicted health and well-being ten days after vacation, explaining an additional $19 \%$ of its variance. Relaxation explained $6 \%$ of additional variance in health/ well-being during vacation when a variety of other predictors were controlled in regression analysis. The relation between relaxation during and health/well-being after vacation, however, did not prove significant (de Bloom et al., 2012). The authors conclude that "the more employees detached from their work and relaxed during vacation, the more they benefitted from vacation in terms of H\&W [health and well-being]" (de Bloom et al., 2012, p. 315). In a similar study, de Bloom, Geurts, and Kompier (2013) reported relaxation during vacation to be significantly related to health/well-being during as well as after vacation. This positive association lasted over four subsequent weeks. In contrast to earlier findings, detachment was not related to health/well-being at any time. The authors attribute this finding to a generally high level of detachment in their sample and the corresponding restriction of range (de Bloom, et al., 2013). Fritz and Sonnentag (2006) studied the compound effect of several vacation experiences (including relaxation) on health complaints immediately after vacation. Although relaxation was correlated to exhaustion, it could not explain any variance in exhaustion during vacation when control variables as well as other vacation experiences were included in the regression analysis. This might be due to associations between relaxation and non-work hassles as well as between relaxation and negative affectivity in their sample.

Summing up, the few studies on recovery experiences during vacation and their link to health and well-being so far show an inconsistent pattern. A missing link in the recovery process during vacation might be the influence of detachment and relaxation on sleep quality. Therefore, in the present study, the relations between recovery experiences (detachment and relaxation) and sleep during vacation were investigated. Sleep problems have been shown to decline from pre- to post-vacation (Strauss-Blasche, Ekmekcioglu, \& Marktl, 2000). Sleep problems is an umbrella term including different operationalization, e.g. sleep efficiency, sleep fragmentation, sleep onset, or subjective sleep quality (Pereira, Meier, \& Elfering, 2013). In a review, McCallie, Blum, and Hood (2006) report a beneficial effect of relaxation on sleep. Although relaxation was defined more broadly in the included studies, a link between relaxation - as defined by Sonnentag and Fritz (2007) - and sleep seems plausible. Previous research points to a negative association between detachment and sleep problems (Elfering, Pereira, Grebner, \& Müller, in press; Pereira \& Elfering, 2014a).

Recovery Experiences as Mediators between Stressors and Sleep Quality / Psychosomatic Complaints Psychological detachment from work can be viewed as the opposite of work-related perseverative cognition, as a lack of detachment includes work-related actions and cognition (Sonnentag \& Bayer, 2005). Although the content of work-related thoughts does not have to be negative, work most often puts some demands on the employee and thinking about work may keep the concomitant activation alive, even during long respites such as a vacation. Feeling aroused is incompatible with the experience of relaxation, which is characterized by low activation (Sonnentag \& Fritz, 2007). So, two possible mechanisms by which job stressors may lead to continued arousal that eventually turns into poor sleep are a lack of psychological detachment and a lack of relaxation.

In a diary study by Pereira and Elfering (2014a), detachment on weekends mediated the effect of social stressors on sleep. That is, people reporting many social stressors at work during the last month were less able to detach on Sunday, which in turn affected their sleep fragmentation and sleep onset 
latency during Sunday night, as assessed by psychophysiological indicators. Also, social exclusion at work appears to be linked to sleep problems as shown in a diary study that used actigraphy for sleep measurement (Pereira et al., 2013). In a population based study detachment was shown to be a mediator of the association between unfairness at work and sleep problems (Elfering et al., in press). Time pressure has also consistently been found to relate to sleep problems (Åkerstedt, Fredlund, Gillberg, \& Jansson, 2002). There is sparse empirical evidence regarding the potential mediating role of relaxation. Kinnunen et al. (2011) considered relaxation as a mediator between job demands and fatigue. Although they could confirm the link between job demands and relaxation, and relaxation was significantly correlated with indicators of fatigue, the path between relaxation and fatigue in the SEM did not reach significance, thus not supporting the mediating role of relaxation. Relaxation has, however, been shown to act as a mediator in other relationships. Off-job activities significantly predicted relaxation (ten Brummelhuis \& Bakker, 2012; Hahn, Binnewies, \& Haun, 2012), which in turn affected next morning vigor (ten Brummelhuis \& Bakker, 2012).

Psychosomatic complaints including headaches and gastrointestinal problems are an important indicator of health and have been shown to be consistently linked with work stressors (Frese, 1985; Nixon et al., 2011). Especially interpersonal stressors at work like social exclusion seem to contribute to the development of psychosomatic health complaints (Zapf \& Frese, 1991). In the current study, the hypothesis is that recovery experiences will mediate the association between time pressure and social exclusion at work before a vacation and sleep quality as well as psychosomatic complaints during vacation.

Mediations are hypothesized to be partial. Complete mediations seem unlikely given additional factors that could potentially mediate the effects, for example vacation activities or lifestyle (Geurts \& Sonnentag, 2006; Härmä, Kompier, \& Vahtera, 2006). Detachment and relaxation were originally defined as two independent experiences that uniquely add to recovery (Sonnentag \& Fritz, 2007). Therefore, detachment and relaxation will be tested simultaneously as unique mediators.

\section{Participants and Design}

\section{Method}

Acquaintances of the first author working at least $40 \%$ (two days a week) who had recently been on vacation were contacted by telephone, email, and social media. Participants were found via advertisement and through snowball sampling, thus establishing a convenience sample. In the advertisement, the study was described as an online survey on work stress, recovery during vacation, and health. Employees were asked for their voluntary participation and informed that the questionnaire would take approximately 35 minutes to complete. They were asked to distribute the link to the questionnaire to friends and family who met the above-mentioned inclusion criteria.

The questionnaire was designed and made accessible to participants via EFS online survey software for academic use. It included various scales assessing job stressors, health, and information concerning the vacation. Only some of these scales were included in the present analyses, others are used as part of a larger study. As the study was conducted in the German-speaking part of Switzerland, all questions were devised in German. The study was performed in consensus with the requirements concerning participants defined by the Swiss Society of Psychology. Study participants were provided information about their rights and guarantee of anonymity.

The sampling procedure does not allow the calculation of any response rate, as it is unknown how many people actually read the advertisement. This is mainly due to the use of social media and the further distribution of the link by the author's acquaintances. A total of 370 people clicked on the link provided and viewed the welcome page. Of them, $263(71 \%)$ viewed the first page of the questionnaire and $221(60 \%)$ pursued to the second page. That is, 221 people actually began completing the questionnaire. However, 85 of these participants $(38 \%)$ ceased the completion midway through the questionnaire, while 136 participants $(62 \%)$ completed the questionnaire up to the last page. Anecdotal data indicates that the length of the questionnaire may have been the main reason for early breaking offs. The ratio of people who activated the link and participants who actually finished the questionnaire is $37 \%$ (136 out of 370$)$.

The final sample consisted of 136 participants from various occupational fields between 20 and 66 years of age $(M=41 ; S D=13.1)$. Sixty-five percent of them were female. Seven percent reported having completed primary education, $38 \%$ reported having completed secondary education, $24 \%, 20 \%$, and $10 \%$ reported holding a bachelor's, master's, or Ph.D. degree, respectively. 


\section{Measures}

In the first part of the questionnaire, participants were asked to think of the last 30 days before their vacation and rate the job stressors for this period. Questions in the second part (concerning recovery experiences and health) referred to the time during vacation.

Time pressure and social exclusion prior to the vacation.

Time pressure at the workplace was assessed using three items designed by Semmer and Kaelin (1999). These go beyond other questionnaires on time pressure intensity by focusing on time pressure that is too high to perform well (Semmer, Kälin, \& Elfering, 2008). Participants rated the following three statements on a 5-point scale ranging from does not apply (1) to fully applies (5): „Time pressure at my workplace... ... is so intense that even my most competent colleagues cannot stand it for a long time" (item 1), „... is so intense, that work-quality is sometimes negatively affected” (item 2), and „...provokes that people must somehow muddle through " (item 3). Cronbach's alpha was .81.

Social exclusion at work was measured using five items based on Leary, Tambor, Terdal, and Downs (1995) and a 5-point scale ranging from does not apply (1) to fully applies (5). Sample Items are „I sometimes get the feeling others avoid me“ and „At work, I often feel like an outsider". Cronbach's alpha of the scale was .58.

\section{Recovery experiences during vacation.}

In order to assess detachment and relaxation, two subscales from the German version of the recovery experiences questionnaire (REQ) by Sonnentag and Fritz (2007) were used. The items were slightly adapted so they concern vacation rather than the evening after a workday. In an earlier study, de Bloom et al. (2011) had investigated the factor structure of a similar adaptation of the REQ to a vacation format and found the same four factors as for the original REQ. The two subscales used in the present research consist of four items each and use a 5-point scale ranging from I do not agree at all (1) to I fully agree (5).

Detachment was assessed using the following items: „During my vacation I don't think about work at all", "During my vacation, I forget about work", "During my vacation, I distance myself from work", and „During my vacation, I get a break from the demands of work“. Cronbach's alpha of the scale was .89.

Relaxation was measured by these items: „During my vacation, I kick back and relax“, "During my vacation, I do relaxing things”, "During vacation, I use the time to relax”, and „During my vacation, I take time for leisure“. Cronbach's alpha of the scale was .84.

\section{Health during vacation.}

Sleep problems were measured using four items from the Insomnia Symptoms Questionnaire by Okun et al. (2009). Participants rated on a 7-point scale, ranging from does not apply at all (1) to fully applies (7), whether statements such as the following applied to their sleep during vacation: „I had trouble falling asleep“ and „I woke up several times during the night“. Cronbach's alpha of the scale was .76.

Psychosomatic complaints were assessed by asking participants to rate how often they had experienced a variety of health complaints during vacation. Twelve items were included such as "gastro-intestinal problems“, „restlessness/ nervousness“, and „lower back pain“. The scale was based on Mohr (1986). Cronbach's alpha was .82. The 5-point scale ranged from rarely/none (1) to frequently/ constantly (5).

\section{Control variables.}

In addition to participants' sex and age, education was assessed inquiring participants' highest educational attainment. A 6-point scale was used ranging from "none" (1) to "Ph.D. (or similar)" (6).

Volume of work was measured to control for any effects of work hours on health (Sparks, Cooper, Fried, \& Shirom, 1997; Härmä, 2006). Participants indicated their volume of work, as contracted, in percentage form. In Switzerland, a volume of $20 \%$ refers to one full working day, $100 \%$ indicating a 42-hours-week.

\section{Analyses}

In all analyses, sex, age, education, and volume of work were included as control variables. Two-tailed tests were used and the alpha level was set to $p<.05$, marking the significance criterion. In order to test the mediation hypothesis, hierarchical regression analyses were computed. Control variables were entered in the first, predictor variables in the second step. Each predictor was tested separately. The mediation hypothesis was tested using Preacher and Hayes' (2008) bootstrap test for estimation of indirect effects (INDIRECT macro for SPSS). Both hypothesized mediators were entered simultaneously. 
Number of bootstrapped resamples was 5000 . Below, $95 \%$ confidence intervals for the estimated indirect effects are reported. All analyses were conducted using SPSS 22.0.

\section{Results}

Means and standard deviations are presented in Table 1 along with the zero-order correlations among all study variables. Time pressure was positively related to psychosomatic complaints $(r=.29, p<.01)$ and sleep problems $(r=.18, p<.05)$, while it was negatively related to detachment $(r=-.28, p<.01)$ and relaxation $(r=-.25, p<.01)$. Social exclusion was positively related to psychosomatic complaints $(r=.19, p<.05)$ and sleep problems $(r=.18, p<.05)$ and negatively related to detachment $(r=-.23, p$ $<.01)$, as well as relaxation $(r=-.23, p<01)$. Furthermore, there was a positive association between time pressure and social exclusion $(r=.17, p<.05)$. Detachment and relaxation were both negatively related to psychosomatic complaints $(r=-.21, p<.01$ and $r=-.29, p<.01$, respectively) as well as sleep problems $(r=-.30, p<.01$ and $r=-.34, p<.01$, respectively). The association between the two recovery experiences was positive and significant $(r=.36, p<01)$, as was the correlation between the two health indicators $(r=.40, p<01)$.

Table 1

Descriptive Statistics and Zero-order Correlations between Study Variables

\begin{tabular}{|c|c|c|c|c|c|c|c|c|c|c|c|c|}
\hline & M & SD & 1 & 2 & 3 & 4 & 5 & 6 & 7 & 8 & 9 & 10 \\
\hline 1. Sex & - & - & - & & & & & & & & & \\
\hline 2. Age & 40.59 & 13.12 & $-.19^{*}$ & - & & & & & & & & \\
\hline 3. Education & - & - & -.04 & $-.21^{*}$ & - & & & & & & & \\
\hline 4. Volume of work & 80.91 & 22.93 & $-.39^{* *}$ & -.01 & .13 & - & & & & & & \\
\hline 5. Time pressure & 2.38 & 0.87 & .02 & -.01 & .12 & .13 & - & & & & & \\
\hline 6. Social exclusion & 1.51 & 0.49 & -.13 & .08 & -.12 & .04 & $.17^{\star}$ & - & & & & \\
\hline 7. Detachment & 3.80 & 0.86 & .03 & -.02 & -.08 & $-.16^{*}$ & $-.28^{* *}$ & $-.23^{\star *}$ & - & & & \\
\hline 8. Relaxation & 4.01 & 0.73 & -.01 & -.02 & .03 & .09 & $-.25^{\star \star}$ & $-.23^{\star *}$ & $.36^{* *}$ & - & & \\
\hline 9. Psych. complaints & 1.67 & 0.55 & $.21^{\star *}$ & $-.21^{* *}$ & $-.16^{*}$ & -.03 & $.29^{* *}$ & $.19^{*}$ & $-.21^{* *}$ & $-.29^{\star *}$ & - & \\
\hline 10. Sleep problems & 2.45 & 1.05 & .10 & .05 & $-.15^{*}$ & -.12 & $.18^{*}$ & $.18^{*}$ & $-.30^{* \star}$ & $-.34^{* *}$ & $.40^{* *}$ & - \\
\hline
\end{tabular}

Table 2

Hierarchical Regression Predicting Health Indicators from Detachment

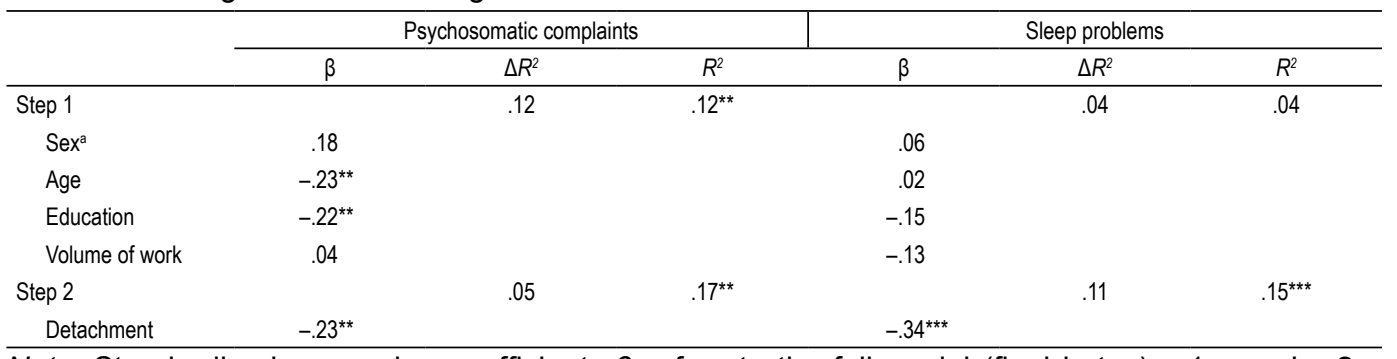

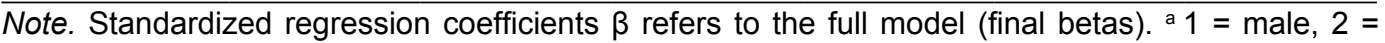
female. $\mathrm{R}^{2}=$ variance explained; $\Delta \mathrm{R}^{2}=$ increase in explained variance. ${ }^{*} p<.05,{ }^{* *} p<.01,{ }^{* * *} p<.001$

Table 3

Hierarchical Regression Predicting Health Indicators from Relaxation

\begin{tabular}{|c|c|c|c|c|c|c|}
\hline & \multicolumn{3}{|c|}{ Psychosomatic complaints } & \multicolumn{3}{|c|}{ Sleep problems } \\
\hline & $\beta$ & $\Delta R^{2}$ & $R^{2}$ & $\beta$ & $\Delta R^{2}$ & $R^{2}$ \\
\hline Step 1 & & .11 & $.11^{\star \star}$ & & .04 & .04 \\
\hline Sex & $.19^{*}$ & & & .08 & & \\
\hline Age & $-.22^{\star *}$ & & & .03 & & \\
\hline Education & $-.20^{*}$ & & & -.13 & & \\
\hline Volume of work & .10 & & & -.04 & & \\
\hline Step 2 & & .09 & $.20^{\star * *}$ & & .11 & $.15^{\star \star \star}$ \\
\hline Relaxation & $-.29^{\star \star *}$ & & & $-.33^{\star \star *}$ & & \\
\hline
\end{tabular}

Note. Standardized regression coefficients $\beta$ refers to the full model (final betas). a $1=$ male, $2=$ female. $\mathrm{R}^{2}=$ variance explained; $\Delta \mathrm{R}^{2}=$ increase in explained variance. ${ }^{*} p<.05,{ }^{* *} p<.01,{ }^{* *} p<.001$

There were some significant correlations with control variables, too. Sex was related to age $(r$ $=-.19, p<05)$, volume of work $(r=-.39, p<01)$ and psychosomatic complaints $(r=.21, p<01)$. On average, women in this sample were younger, worked fewer hours per week and reported suffering from 
more psychosomatic complaints than men. Age was negatively related to education $(r=-.21, p<05)$ and psychosomatic complaints $(r=-.21, p<01)$, while education was negatively related to psychosomatic complaints $(r=-.16, p<05)$ and sleep problems $(r=-.15, p<05)$. Moreover, volume of work was negatively related to detachment $(r=-.16, p<05)$ with employees working more hours a week reporting less psychological detachment from work.

As all correlations of interest were significant and in the predicted direction, further analyses could be conducted on the data. In order to control for associations between control and study variables, the control variables were included in all of the following analyses.

Before conducting the mediation analyses, it was confirmed whether an association between job stressors and health could be detected in hierarchical regression analyses (see Tables 4 and 5). Time pressure was significantly related to psychosomatic complaints $\left(\beta=.31, t(130)=3.93, p=.000, \Delta R^{2}=\right.$ .09 ) and sleep problems $\left(\beta=.21, t(130)=2.50, p=.014, \Delta R^{2}=.04\right)$. Social exclusion, too, was related to psychosomatic complaints $\left(\beta=.21, t(130)=2.52, p=.013, \Delta R^{2}=.04\right)$ and sleep problems $(\beta=.18$, $\left.t(130)=2.13, p=.035, \Delta R^{2}=.03\right)$.

Table 4

Hierarchical Regression Predicting Recovery Experiences and Health Indicators from Time Pressure

\begin{tabular}{|c|c|c|c|c|c|c|c|c|c|c|c|c|}
\hline & \multicolumn{3}{|c|}{ Detachment } & \multicolumn{3}{|c|}{ Relaxation } & \multicolumn{3}{|c|}{$\begin{array}{l}\text { Psychosomatic } \\
\text { complaints }\end{array}$} & \multicolumn{3}{|c|}{ Sleep problems } \\
\hline & $\beta$ & $\Delta R^{2}$ & $R^{2}$ & $\beta$ & $\Delta R^{2}$ & $R^{2}$ & $\beta$ & $\Delta R^{2}$ & $R^{2}$ & $\beta$ & $\Delta R^{2}$ & $R^{2}$ \\
\hline Step 1 & & .03 & .03 & & .01 & .01 & & .12 & $.12^{* *}$ & & .04 & .04 \\
\hline Sex & -.02 & & & .05 & & & .16 & & & .06 & & \\
\hline Age & -.03 & & & .00 & & & $-.23^{* \star}$ & & & .03 & & \\
\hline Education & -.04 & & & .05 & & & $-.24^{* *}$ & & & -.15 & & \\
\hline Volume of work & -.13 & & & .14 & & & .03 & & & -.11 & & \\
\hline Step 2 & & .07 & $.10^{* *}$ & & .07 & $.08^{* *}$ & & .09 & $.21^{* *}$ & & .04 & $.08^{*}$ \\
\hline Time pressure & $-.26^{\star \star}$ & & & $-.27^{\star *}$ & & & $.31^{* * *}$ & & & $.21^{*}$ & & \\
\hline
\end{tabular}

Note. Standardized regression coefficients $\beta$ refers to the full model (final betas). ${ }^{a} 1=$ male, $2=$ female. $\mathrm{R}^{2}=$ variance explained; $\Delta \mathrm{R}^{2}=$ increase in explained variance. ${ }^{*} p<.05,{ }^{* \star} p<.01,{ }^{* \star *} p<$ .001 .

Table 5

Hierarchical Regression Predicting Recovery Experiences and Health Indicators from Social Exclusion

\begin{tabular}{lccccccc|ccc|ccc}
\hline & \multicolumn{3}{c}{ Detachment } & \multicolumn{3}{c}{ Relaxation } & \multicolumn{3}{c}{$\begin{array}{c}\text { Psychosomatic } \\
\text { complaints }\end{array}$} \\
\cline { 2 - 13 } & $\beta$ & $\Delta R^{2}$ & $R^{2}$ & $\beta$ & $\Delta R^{2}$ & $R^{2}$ & $\beta$ & $\Delta R^{2}$ & $R^{2}$ & $\beta$ & $\Delta R^{2}$ & $R^{2}$ \\
\hline Step 1 & & .03 & .03 & & .01 & .01 & & .12 & $.12^{* *}$ & & .04 & .04 \\
$\quad$ Sex & -.07 & & & -.01 & & & $.21^{*}$ & & & .10 & & \\
Age & -.03 & & & -.01 & & & $-.22^{* *}$ & & & .03 & & \\
$\quad$ Education & -.09 & & & -.01 & & & $-.18^{*}$ & & & -.11 & & \\
$\quad$ Volume of work & -.16 & & & .10 & & & .07 & & & -.08 & & \\
Step 2 & & .06 & $.09^{* *}$ & & .05 & $.06^{* *}$ & & .04 & $.16^{*}$ & & .03 & $.07^{*}$ \\
$\quad$ Time pressure & $-.25^{* *}$ & & & $-.23^{* *}$ & & & $.21^{*}$ & & & $.18^{*}$ & & \\
\hline
\end{tabular}

Note. Standardized regression coefficients $\beta$ refers to the full model (final betas). ${ }^{\text {a }} 1=$ male, $2=$ female. $\mathrm{R}^{2}=$ variance explained; $\Delta \mathrm{R}^{2}=$ increase in explained variance. ${ }^{*} p<.05,{ }^{* *} p<.01,{ }^{* * *} p<$ .001 .

With all associations being in line with the mediation hypothesis, detachment and relaxation were tested as mediators in the association between job stressors before vacation and health during vacation. Figures 1 to 4 depict direct effects, total effects, as well as estimated indirect effects. Table 6 displays corresponding confidence intervals. 
Figure 1

Indirect effect of time pressure on psychosomatic complaints through recovery experiences. Unstandardized regression coefficients.

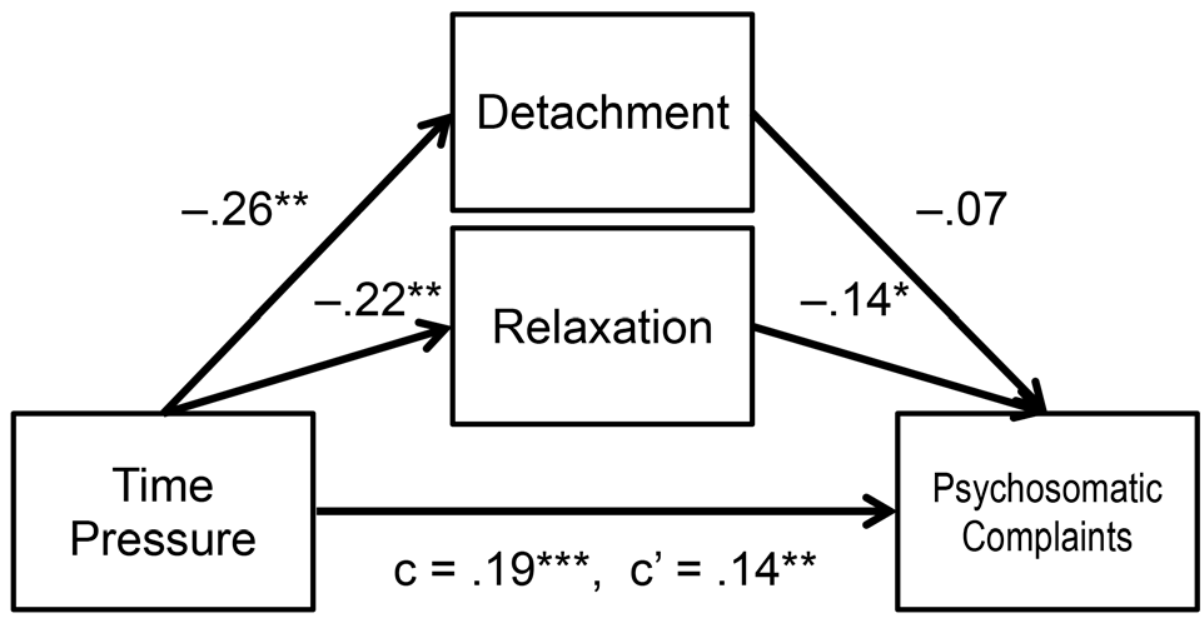

${ }^{*} p<.05,{ }^{* *} p<.01,{ }^{* * *} p<.001$.

Figure 2

Indirect effect of time pressure on sleep problems through recovery experiences. Unstandardized regression coefficients.

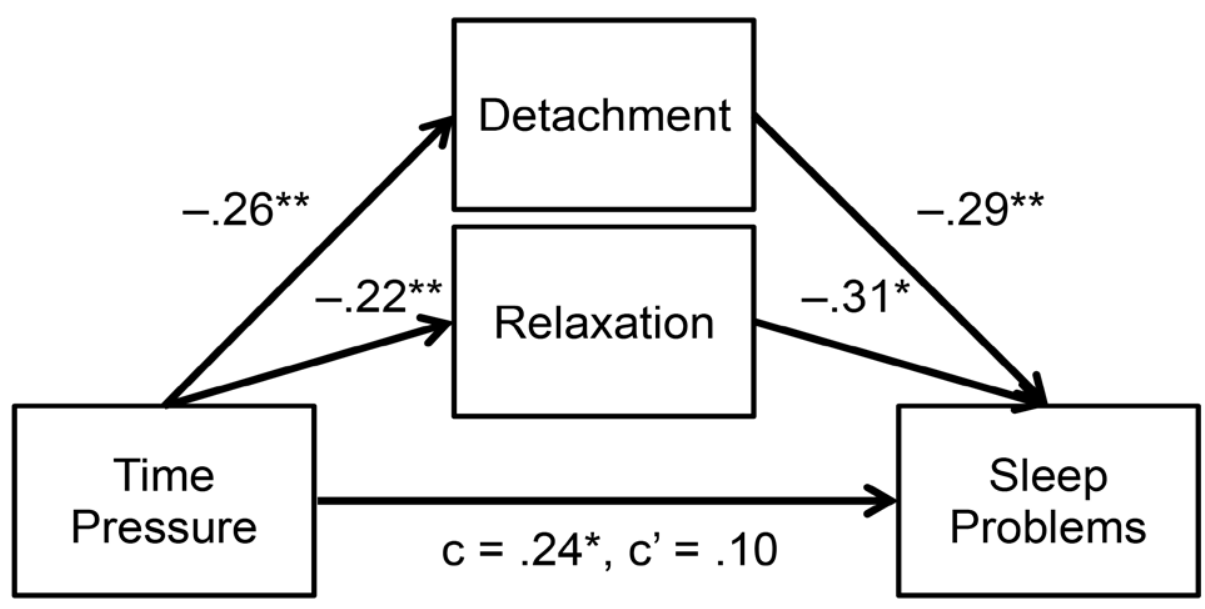

${ }^{*} p<.05,{ }^{* *} p<.01,{ }^{* * *} p<.001$.

Figure 3

Indirect effect of social exclusion on psychosomatic complaints through recovery experiences. Unstandardized regression coefficients.

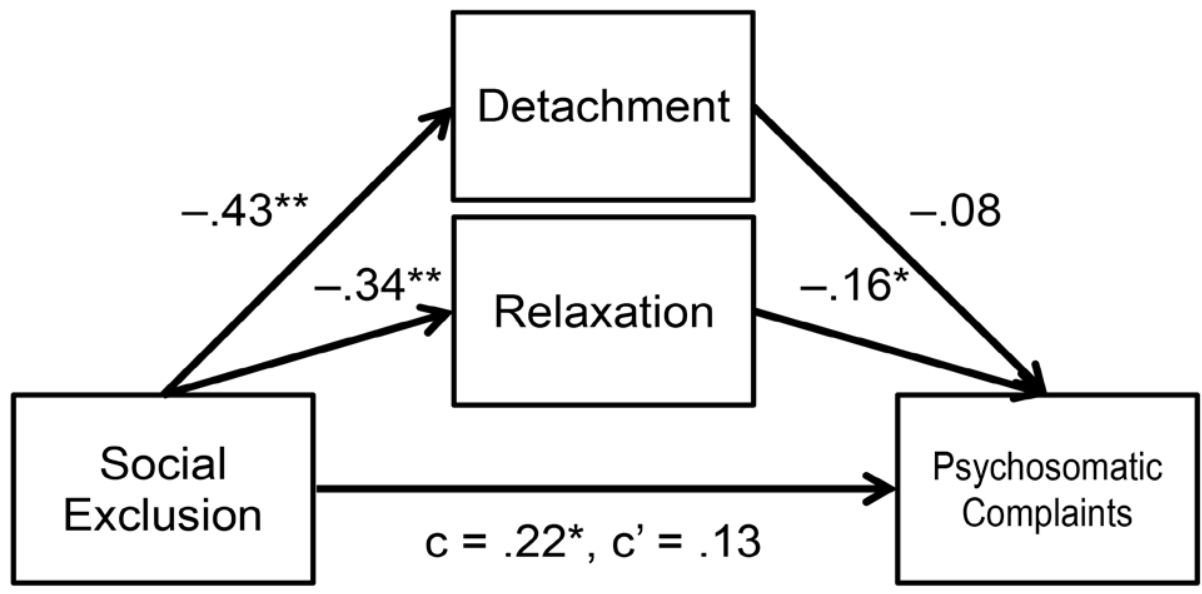

${ }^{*} p<.05,{ }^{* *} p<.01,{ }^{* * *} p<.001$. 
Figure 4

Indirect effect of social exclusion on sleep problems through recovery experiences. Unstandardized regression coefficients.

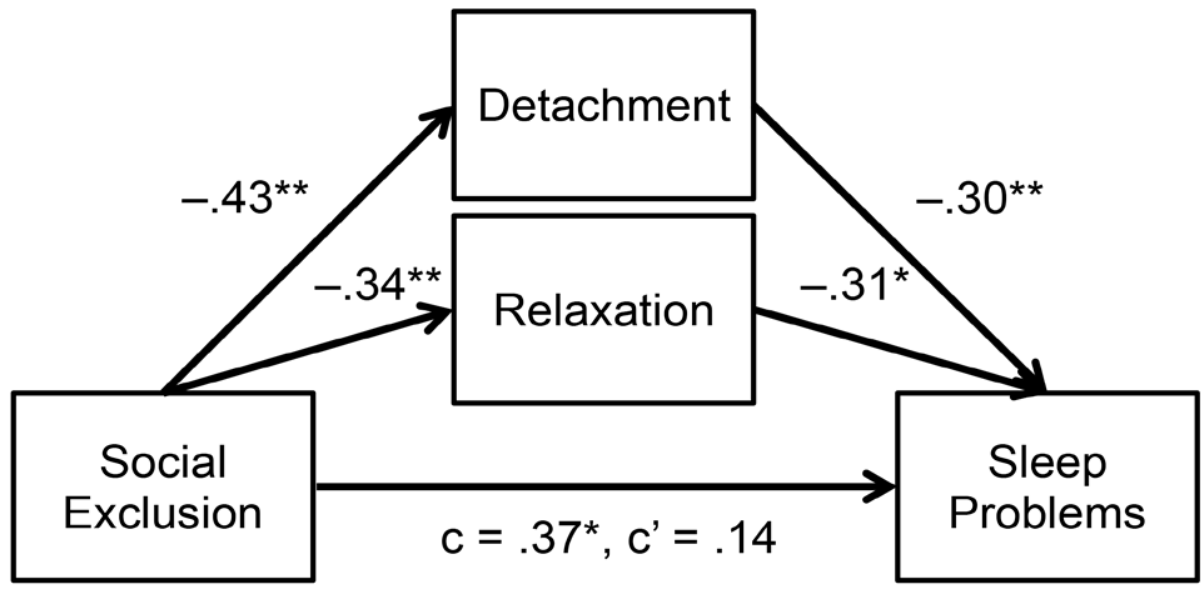

${ }^{*} p<.05,{ }^{* *} p<.01,{ }^{* * *} p<.001$.

Table 6

Unstandardized Direct and Indirect Effects of Job Stressors on Health through Recovery Experiences

\begin{tabular}{|c|c|c|c|c|}
\hline Proposed Mediation & $\mathrm{TiPr} \rightarrow \operatorname{RecExp} \rightarrow$ PsySom & $\mathrm{TiPr} \rightarrow \operatorname{Rec} \operatorname{Exp} \rightarrow \mathrm{SI}$ & SocEx $\rightarrow$ RecExp $\rightarrow$ PsySom & SocEx $\rightarrow$ RecExp $\rightarrow$ Sl \\
\hline IV $\rightarrow$ Det & $-.26^{* *}$ & $-.26^{* \star}$ & $-.43^{* *}$ & $-.43^{* *}$ \\
\hline Det $\rightarrow$ DV & -.07 & $-.29^{* \star}$ & -.08 & $-.30^{\star *}$ \\
\hline Indirect effect through Det (95Cl) & $\begin{array}{c}.02 \\
(-.0070 \text { to } .0641)\end{array}$ & $\begin{array}{c}.08 \\
(.0199 \text { to } .1798)\end{array}$ & $\begin{array}{c}.03 \\
(-.0096 \text { to } .1098)\end{array}$ & $\begin{array}{c}.13 \\
(.0366 \text { to } .2974)\end{array}$ \\
\hline IV $\rightarrow$ Rel & $-.22^{* *}$ & $-.22^{* \star}$ & $-.34^{* *}$ & $-.34^{* *}$ \\
\hline $\mathrm{Rel} \rightarrow \mathrm{DV}$ & $-.14^{*}$ & $-.31^{*}$ & $-.16^{*}$ & $-.31^{*}$ \\
\hline Indirect effect through Rel (95Cl) & $\begin{array}{c}.03 \\
(.0057 \text { to } .0778)\end{array}$ & $\begin{array}{c}.07 \\
\text { (.0153 to } .1626)\end{array}$ & $\begin{array}{c}.05 \\
(.0096 \text { to } .1404)\end{array}$ & $\begin{array}{c}.11 \\
(.0203 \text { to } .2837)\end{array}$ \\
\hline Total indirect effect $(95 \mathrm{Cl})$ & $\begin{array}{c}.05 \\
.0159 \text { to } .0952)\end{array}$ & $\begin{array}{c}.14 \\
(.0607 \text { to } .2662)\end{array}$ & $\begin{array}{c}.09 \\
(.0263 \text { to } .1801)\end{array}$ & $\begin{array}{c}.23 \\
(.0915 \text { to } .4730)\end{array}$ \\
\hline Direct effect (IV $\rightarrow$ DV) & $.14^{\star \star}$ & .10 & .13 & .14 \\
\hline Total effect (IV $\rightarrow$ DV) & $.19^{* * *}$ & $.24^{*}$ & $.22^{\star}$ & $.37^{*}$ \\
\hline Explained variance in $\mathrm{DV}\left(R^{2}\right)$ & $.26^{* * *}$ & $.22^{* * *}$ & $.23^{* \star *}$ & $.22^{* \star *}$ \\
\hline
\end{tabular}

Note. Det $=$ detachment; Rel $=$ relaxation; RecExp = recovery experiences. $\mathrm{TiPr}=$ time pressure SocEx = social exclusion. PsySom = psychosomatic complaints; $\mathrm{SI}=$ sleep problems. IV = independent variable (time pressure or social exclusion); $\mathrm{DV}=$ dependent variable (psychosomatic complaints or sleep problems). $95 \mathrm{Cl}=95 \%$ confidence interval. When the $\mathrm{Cl}$ does not include zero, the indirect effect is considered significant. ${ }^{*} p<.05$. ${ }^{* *} p<.01 .{ }^{* * *} p<.001$.

For the relation of time pressure and psychosomatic complaints, relaxation was confirmed to act as a mediator $(\mathrm{B}=.03, \mathrm{Cl} 95=.0057$ to .0778$)$ while detachment was not $(\mathrm{B}=.02, \mathrm{Cl} 95=-.0070$ to .0641). Though the total indirect effect through both recovery experiences $(B=.05 ; C l 95=.0159$ to .0952) was bigger than the indirect effect through relaxation alone, the indirect effect through detachment was not statistically significant. As the direct effect of time pressure on psychosomatic complaints remained significant $\left(c^{\prime} B=.14, t(n=127)=2.78, p=.01\right)$ when both recovery experiences were considered as mediators, the mediation was partial.

Both detachment $(B=.08, C 195=.0199$ to .1798$)$ and relaxation $(B=.07, C 195=.0153$ to .1626$)$ were found to mediate between time pressure and sleep problems with a total indirect effect of $B=.14$ $(\mathrm{Cl} 95=.0607$ to .2662$)$. Recovery experiences fully mediated between time pressure and sleep problems, since the direct effect became non-significant in the mediation analysis $\left(c^{\prime} B=.10, t(n=127)=\right.$ $.99, p=.33)$.

Regarding the relation between social exclusion and psychosomatic complaints, again only relaxation was found to act as a mediator $(B=.05, C 195=.0096$ to .1404$)$. Though there was a bigger total indirect effect $(\mathrm{B}=.09 ; \mathrm{Cl} 95=.0263$ to .1801$)$, the mediating role of detachment could not be confirmed $(B=.03, C l 95=-.0096$ to .1098$)$. Relaxation fully mediated the effect of social exclusion on psychosomatic complaints, as the direct effect remained no longer significant $\left(c^{\prime} B=.13, t(n=127)=1.48, p=\right.$ .14). 
Both recovery experiences mediated between social exclusion and sleep problems with a total indirect effect of $B=.23(C I 95=.0915$ to .4730$)$. The indirect effect through detachment was $B=.13$ $(\mathrm{Cl} 95=.0366$ to .2974$)$, the one through relaxation was $\mathrm{B}=.11(\mathrm{Cl} 95=.0203$ to .2837$)$. The direct effect of social exclusion on sleep problems with both mediators in the model was non-significant ( $c^{\prime} B=.14$, $t(n=127)=.80, p=.43)$, indicating full mediation.

\section{Discussion}

The present research aimed to shed light on the relation between job stressors prior to vacation, recovery experiences during vacation, and employees' sleep problems and psychosomatic complaints during vacation. Psychological detachment from work and relaxation during vacation were expected to partially mediate between job stressors, that is, time pressure and social exclusion, prior to vacation and psychosomatic complaints and sleep problems during vacation. The indirect effects through recovery experiences fully or partially accounted for the detected relations between job stressors and both indicators of health. The findings illustrate that the association between both job stressors and sleep problems was fully mediated by detachment and relaxation. Relaxation partially mediated between time pressure and psychosomatic complaints and fully mediated between social exclusion and psychosomatic complaints while detachment was no mediator in prediction of psychosomatic complaints. The current study is the first to show a relation between job stressors prior to vacation and recovery experiences during vacation.

Time pressure was found to predict psychosomatic complaints and relaxation was confirmed as a partial mediator in between. There may, therefore, be additional intervening factors. For example, lifestyle and vacation activities are likely to play a role in these relations as well (Geurts \& Sonnentag, 2006). High job stressors might diminish the possibility to pre-arrange a vacation that suits one's needs due to a lack of resources such as time, attention, or energy. In a similar vein, after a highly stressful time, one might feel too exhausted to pursue pleasant activities during vacation and be more likely to engage in passive activities, which often do not add to recovery (Sonnentag \& Zijlstra, 2006). Moreover, unhealthy lifestyles during vacation can be viewed as a consequence of high work stress (Sonnentag $\&$ Jelden, 2009). These and other factors may also mediate between time pressure at work and health complaints during vacation.

Relaxation was more consistently confirmed as a mediator than was detachment.. Both concepts were tested simultaneously in mediation tests of the current study because psychological detachment and relaxation were originally defined as two independent experiences that uniquely add to recovery (Sonnentag \& Fritz, 2007). Kinnunen et al. (2011), however suggested that detachment might be a prerequisite for relaxation, that is, employees might have to detach from work before being able to relax. Detachment might indeed be viewed as one precondition for relaxation, a construct closer to physiological unwinding. This assumption is consistent with the notion of cognitive factors as antecedents of insufficient unwinding (Brosschot, Pieper, \& Thayer, 2005). Investigating the dynamics between detachment and relaxation in future studies might, therefore, be more fruitful than further treating the two experiences as widely independent constructs. Studies testing detachment as a precursor of relaxation should be longitudinal and based on daily experiences.

In the present study, sleep and psychosomatic complaints were investigated as two parallel indicators of health. It might, however, be more appropriate to view sleep problems as an important precursor of psychosomatic and other complaints (Åkerstedt, 2006; Elfering et al., in press). Nixon et al. (2011) suggested a relatively immediate effect of occupational stressors on gastrointestinal complaints and sleep, while other symptoms such as backache or headache appear to develop more gradually over time. One possibility to gain more objective measures of sleep problems is the use of actigraphs (Ancoli-Israel et al., 2003). For instance, in applying a longitudinal ambulatory research design with actigraphy-based sleep assessments across multiple nights, Pereira and Elfering (2014b) determined sleep fragmentation as a mediator between social stressors at work and psychosomatic complaints. As participants are only required to wear a small wristband during the night, the use of actigraphs is particularly suitable for home recordings (Ancoli-Israel et al., 2003). It has previously been used in research on recovery (Pereira \& Elfering, 2014a, 2014b) and seems to be convenient for use in vacation studies. Nighttime actigraphy during vacation in future studies will allow to test sleep problems as an antecedent of psychosomatic complaints during vacation.

The current findings indicate that employees who experience stressful conditions at work may be less able to benefit from a vacation. The paradoxical nature of a high need for recovery combined with the inability to recover has been reported before. For example, Sonnentag and Fritz (2014) describe the gradual development of a chronic inability to detach when employees regularly encounter job stressors. 
They argue that a longer respite such as a vacation may be necessary to break the negative spiral of job stressors, lack of detachment, and chronically elevated strain levels. The findings of the current study, however, point to the fact that even during vacation, psychological detachment and relaxation may be hampered by preceding job stressors. Job stressors entail a loss of resources, e.g. self-regulation (Muraven \& Baumeister, 2000; Sonnentag \& Jelden, 2009) and might thus impair the ability to detach and relax deliberately.

While theoretical assumptions and empirical findings illustrate why time pressure and social exclusion at work are particularly stressful and prone to impede recovery experiences (Brosschot et al., 2005; Gerber \& Wheeler, 2009; Sonnentag, 2012; Sonnentag \& Fritz, 2007; Ursin \& Eriksen, 2004) and health (Åkerstedt et al., 2002; Gemzøe Mikkelsen \& Einarsen, 2002; Grebner et al., 2003; Höge, 2009; Pereira et al., 2013), there is need to test other job stressors. Other social stressors (Pereira \& Elfering, 2014a; Volmer, Binnewies, Sonnentag, \& Niessen, 2012), the experience of injustice at work (Siltaloppi, Kinnunen, \& Feldt, 2009), and job insecurity (Kinnunen, Mauno, \& Siltaloppi, 2010) might hinder relaxation experiences during vacation as well and, thus, lead to health impairments in the long run. The general mechanisms of stress and recovery, however, are likely to be the same as the ones found in the present research.

\section{Limitations}

The main drawback of the current research is the cross-sectional design, which reduces the validity of the findings and their interpretation. Internal validity is also jeopardized by the retrospective inquiry of participants, the reliance on self-reports only and the lack of control of other potentially influencing factors. These include vacation activities, negative incidents during vacation, health behavior during vacation, or personality factors. Studies should assess individual perceptions of recovery barriers during vacation like an increased risk perception or fear of local crime, etc.

Most importantly, the reliance on one measuring time precludes causal interpretation of the results. Reverse causation is conceivable. For example, employees who experience poor health during vacation might be less able to relax due to pain and perceive their jobs as more stressful. The use of self-reports only may inflate correlations, as response biases (such as acquiescence) influence the assessment of job stressors, recovery experiences, and health alike (Semmer, Grebner, \& Elfering, 2004). It cannot be ruled out, for example, that personal characteristics or mood at the time the questionnaire was completed influenced how participants retrospectively rated job stressors and vacation experiences. Thus, the application of different assessment methods would be favorable to prevent common method variance and achieve better triangulation (de Bloom et al., 2013; Semmer et al., 2004). Job stressors before vacation could be additionally assessed by direct observation (Grebner, Semmer, \& Elfering, 2005) or peer ratings (Demsky, Ellis, \& Fritz, 2014). Although recovery experiences constitute highly subjective constructs that rely on personal perception, they have been successfully assessed by significant others in previous research (Sonnentag \& Kruel, 2006; Sonnentag, Kuttler, \& Fritz, 2010). In addition, researchers may rely on projective assessments, e.g., ask participants to make drawings of vacation experiences (Korstanje, 2010).

External validity of the findings is likely reduced by the sampling procedure (convenience sample, that is, a non-probability sample) as well as the composition of the sample. It is not clear if people who chose to click on the link to the online questionnaire differed in any way from those who did not, nor is any information available on differences between participants who fully completed the questionnaire and those who stopped before getting to the last page. It seems plausible, for example, that people suffering from high time pressure may not have had the time and patience to complete the whole questionnaire, constituting a potential bias. Of all participants, $65 \%$ were women and $54 \%$ held at least a bachelor's degree. As the percentage of Swiss adults with a bachelor's degree or a higher education is lower than $40 \%$ (Bundesamt für Statistik, 2013), the current sample can be viewed as highly educated. In previous research, the effect of vacation were the same for women and men (Kühnel \& Sonnentag, 2011; Strauss-Blasche et al., 2000), employees from different occupational fields (Strauss-Blasche et al., 2000), and part-time versus full-time employees (de Bloom et al., 2011). Still, caution is warranted in generalizing the present results. When comparing the means of detachment and relaxation during vacation to those obtained in other investigations (de Bloom et al., 2012, 2013), the employees in the present research were somewhat less able to detach and relax. Whether this difference is due to chance or any specific characteristic of the sample, remains to be clarified in future research. As research on vacation has, to date, been conducted by a small group of authors only, replications and extensions from other researchers are clearly needed. 
The main benefit of this study is the unprecedented focus on occupational stressors, recovery experiences, and health in the context of vacation. The findings are strengthened through the investigation of two different job stressors, recovery experiences, and health indicators, respectively. Although the results have to be considered with caution, they tentatively suggest that previous findings from research focusing on recovery during evenings and weekends might apply to longer periods of respite as well, and that job stressors might negatively affect health during vacation through a lack of specific recovery experiences.

\section{Practical Implications}

Especially if replicated with a stronger methodology, the present findings would have important implications. In order to promote recovering vacations, individual as well as organizational interventions aiming at improved recovery experiences appear to be beneficial. Evidence from clinical psychology and intervention studies illustrates how the individual's ability to detach and relax can be fostered, which might buffer against adverse effects of job stressors on health. Research on progressive muscle relaxation, a technique reducing tension and inducing relaxation (Jacobson, 2011), shows beneficial effects on various physiological parameters and a variety of health indicators (McCallie et al., 2006). Detachment might be fostered through programs targeting mindfulness and worries (Eatough, 2015). Mindfulness is the ability to attend to the present moment (Klatt, Buckworth, \& Malarkey, 2008) and therefore encompasses psychological detachment from work during leisure time. Mindfulness-based stress-reduction (MBSR; Kabat-Zinn, 2003) is a technique with positive effects on mental and physical health (Grossman, Niemann, Schmidt, \& Walach, 2004). Klatt et al. (2008) implemented a short version of MBSR at the workplace and report effects on mindfulness, perceived stress, and several subjective sleep indicators. In an investigation by Brosschot and van der Doef (2006), a very simple intervention from cognitive behavioral therapy (postponement of worries to a daily worry period of 30 minutes) decreased worry duration as well as psychosomatic complaints in adolescents over the course of one week. Although the two constructs are distinct, worries and psychological detachment overlap to some extent (Sonnentag \& Fritz, 2014). Thus, a similar intervention might be effective in fostering detachment from work and could easily be applied during vacation. Hahn, Binnewies, Sonnentag, and Mojza (2011) developed a training program specifically targeting recovery experiences. The training consists of two sessions with a total duration of nine hours and teaches various strategies on arranging one's leisure time and managing boundaries between work and leisure. It yields positive effects on recovery experiences. Moreover, effects on health and well-being (e.g. perceived stress, sleep quality) are reported. It appears possible, therefore, to directly stimulate the individual's ability to relax and detach from work during vacation.

However, individual interventions and strategies alone might not be sufficient to assure recovery during vacation and other periods off-work. The present findings indicate that the ability to detach and relax during vacation might be negatively affected by stressful work conditions. Safstrom and Hartig (2013) argue that detachment may be "less subject to individual differences than to the imposition of stressors" (p. 418) and that particularly under conditions of high job stressors, detachment might be difficult to achieve. Thus, organizational arrangements targeting job stressors appear to be necessary to complement individual interventions aimed at promoting recovery experiences (Sonnentag \& Fritz, 2014). This is in line with Semmer and Kottwitz' (2011) notion that job design is the best way to promote employees' recovery during leisure time: Summarizing the extensive evidence on job design and work stress, the authors suggest designing work hours (frequent breaks, fewer work hours per week), promoting meaningful tasks that are manageable yet challenging, ergonomic adaptations, family friendly work arrangements, as well as creating a respecting and appreciating social environment at work.

Accordingly, some studies illustrate how social exclusion at work and high time pressure might be targeted. Robinson, O'Reilly, and Wang (2013) offer an integrated model of workplace ostracism and identify some organizational factors influencing social exclusion at work. Among them are organizational norms, interdependence, and group identification. Researchers on social exclusion at work highlight the importance of raising awareness of ostracism, applying cooperation-based incentive systems (Scott, 2007), and discouraging exclusionary behavior at the workplace (Scott, Restubog, \& Zagenczyk, 2013). An intervention study demonstrates a reduction in workplace ostracism through the promotion of mindfulness (Ramsey \& Jones, 2015). Although counteracting social exclusion at work is complex, it seems crucial to protect employees' health and allow them to recover successfully.

Concerning time pressure and workload, Sonnentag (2012) illustrates how time pressure and detachment are linked: The more time pressure at work, the more employees report a lack of detachment. Accordingly, reducing workload may be a straightforward way to enhance psychological detachment from work. As employees often face a particularly high workload immediately before vacation (de Bloom 
et al., 2013), organizational arrangements that allow employees to finish tasks before vacation or yield them to a competent colleague might foster recovery experiences during vacation.

The supervisor's behaviors as well as organizational guidelines communicate expectations to employees concerning their availability during leisure time, which is referred to as segmentation norm (Park, Fritz, \& Jex, 2011). When employees experience a low segmentation norm, and when they stay connected to their job during evening times through the use of communication technology (e.g. emails, smartphones), they experience a lack of psychological detachment (Park et al., 2011; Derks, Mierlo, \& Schmitz, 2014) as well as an elevated interference between the work and home domain (Derks \& Bakker, 2012). Organizational norms regarding a high segmentation of work and leisure during vacation might therefore help employees detach from their work. Work-related activities during vacation have been shown to be negatively associated with psychological detachment as well as health and well-being (de Bloom et al., 2012). As a high workload is likely to lead employees to work during their vacation (de Bloom, Geurts, \& Kompier, 2010), again, reducing workload seems to be crucial to enable sufficient recovery during vacation.

After resuming work following a vacation, the beneficial effects of vacation fade quickly (de Bloom et al., 2009; Kühnel \& Sonnentag, 2011; Westman \& Etzion, 2001). Especially a high workload after vacation affects well-being and effort-expenditure at work (Fritz \& Sonnentag, 2006; Strauss-Blasche, Ekmekcioglu, \& Marktl, 2002). Studies should more often focus on the contrasting change from vacation to work and its effects that were described - like a higher risk of divorce and a post-vacation blues syndrome (Korstanje, 2016). The anticipation of a high workload upon returning might account for the drop in health and well-being towards the end of a vacation (de Bloom et al., 2013). The current findings imply that reducing workload and time pressure are probably effective precautions that enhance recovery during and after vacation.

The rather short-lived effects of vacation, however, may also be prolonged through arrangements that are more under the individual's control. Relaxation after vacation has been found to extend the beneficial effects of vacation on exhaustion (Kühnel \& Sonnentag, 2011). Vacation reflection is another factor that may possibly prolong vacation effects. Actively collecting memorabilia, taking photographs, or writing a vacation journal can help savoring during vacation as well as vacation reflection afterwards (de Bloom, Geurts, \& Kompier, 2010; de Bloom, Geurts, Taris, et al., 2010). As positive emotions can speed up cardiovascular recovery (Fredrickson, Mancuso, Branigan, \& Tugade, 2000), reminiscence on a recent vacation might slow down the fade-out of vacation effects.

Most importantly, however, recovery on a regular basis seems vital to protect employees' health (Semmer \& Kottwitz, 2011) and frequent respites are supposed to be more beneficial than the duration of a single vacation (de Bloom et al., 2013). When the need for recovery before vacation is only moderate, recovery during vacation might occur more rapidly, leaving more time for additional resources to build up. These include, for example, a supportive relationship with the partner (de Bloom et al., 2012) and gaining another perspective on life (de Bloom et al., 2013).

\section{Conclusion}

While the negative effects of not taking any vacations have been documented (Gump \& Matthews, 2000), evidence on beneficial long-term effects of vacations (e.g. long-term workability) is still lacking (de Bloom et al., 2013). Moreover, the investigation of possible mechanisms leading to recovery during vacation has only just begun. The current findings suggest that psychological detachment from work and relaxation during vacation are crucial recovery experiences that mediate between stressful work conditions and employee's health. A replication of these findings applying a longitudinal design would enhance our understanding of recovery during vacation and its prerequisites. The present study adds to the growing evidence on recovery during shorter periods off work such as evenings or weekends. Vacations seem crucial to complement daily and weekly recovery and protect employees' health in the long run. However, individual as well as organizational measures need to be taken to facilitate restorative vacations.

\section{References}

1. Åkerstedt, T. (2006). Psychosocial stress and impaired sleep. Scandinavian Journal of Work, Environment and Health, 32, 493-501. https://doi.org/10.5271/sjweh.1054

2. Åkerstedt, T., Fredlund, P., Gillberg, M., \& Jansson, B. (2002). Work load and work hours in relation to disturbed sleep and fatigue in a large representative sample. Journal of Psychosomatic Research, 53, 585-588. https://doi.org/10.1016/S0022-3999(02)00447-6 
3. Ancoli-Israel, S., Cole, R., Alessi, C., Chambers, M., Moorcroft, W., \& Pollak, C. (2003). The role of actigraphy in the study of sleep and circadian rhythms. Sleep, 26(3), 342-392.

4. de Bloom, J., Geurts, S., \& Kompier, M. (2010). Vacation from work as prototypical recovery opportunity. Gedrag en Organisatie, 23(4), 333-349.

5. de Bloom, J., Geurts, S. A., \& Kompier, M. A. (2012). Effects of short vacations, vacation activities and experiences on employee health and well-being. Stress and Health, 28, 305-318. https://doi. org/10.1002/smi.1434

6. de Bloom, J., Geurts, S. A., \& Kompier, M. A. (2013). Vacation (after-) effects on employee health and well-being, and the role of vacation activities, experiences and sleep. Journal of Happiness Studies, 14, 613-633. https://doi.org/10.1007/s10902-012-9345-3

7. de Bloom, J., Geurts, S. A., Sonnentag, S., Taris, T., de Weerth, C., \& Kompier, M. A. (2011). How does a vacation from work affect employee health and well-being? Psychology and Health, 26, 1606-1622. https://doi.org/10.1080/08870446.2010.546860

8. de Bloom, J., Geurts, S. A., Taris, T. W., Sonnentag, S., de Weerth, C., \& Kompier, M. A. (2010). Effects of vacation from work on health and well-being: Lots of fun, quickly gone. Work and Stress, 24, 196-216. https://doi.org/10.1080/02678373.2010.493385

9. de Bloom, J., Kompier, M., Geurts, S. A., de Weerth, C., Taris, T., \& Sonnentag, S. (2009). Do we recover from vacation? Meta-analysis of vacation effects on health and well-being. Journal of Occupational Health, 51, 13-25. https://doi.org/10.1539/joh.K8004

10. Bakker, A. B., \& Demerouti, E. (2007). The job demands-resources model: State of the art. Journal of Managerial Psychology, 22, 309-328. https://doi.org/10.1108/02683940710733115

11. Bundesamt für Statistik (2013). Bildungsstand der Bevölkerung. Retrieved from http://www.bfs. admin.ch/bfs/portal/de/index/themen/15/17/blank/01.indicator.406101.4086.html?open=9\#9

12. Brosschot, J. F., Pieper, S., \& Thayer, J. F. (2005). Expanding stress theory: Prolonged activation and perseverative cognition. Psychoneuroendocrinology, 30, 1043-1049. https://doi. org/10.1016/i.psyneuen.2005.04.008

13. Brosschot, J. F., \& van der Doef, M. (2006). Daily worrying and somatic health complaints: Testing the effectiveness of a simple worry reduction intervention. Psychology and Health, 21, 19-31. https://doi.org/10.1080/14768320500105346

14. ten Brummelhuis, L. L., \& Bakker, A. B. (2012). Staying engaged during the week: The effect of off-job activities on next day work engagement. Journal of Occupational Health Psychology, 17, 445-455. https://doi.org/10.1037/a0029213

15. Demsky, C. A., Ellis, A. M., \& Fritz, C. (2014). Shrugging it off: Does psychological detachment from work mediate the relationship between workplace aggression and work-family conflict? Journal of Occupational Health Psychology, 19, 195-205. https://doi.org/10.1037/a0035448

16. Derks, D., \& Bakker, A. B. (2012). Smartphone use, work-home interference, and burnout: A diary study on the role of recovery. Applied Psychology: An International Review, 63, 411-440. https:// doi.org/10.1111/j.1464-0597.2012.00530.x

17. Derks, D., van Mierlo, H., \& Schmitz, E. B. (2014). A diary study on work-related smartphone use, psychological detachment and exhaustion: Examining the role of the perceived segmentation norm. Journal of Occupational Health Psychology, 19, 74-84. https://doi.org/10.1037/a0035076

18. Eatough, E. M. (2015). How does employee mindfulness reduce psychological distress? Industrial and Organizational Psychology, 8(04), 643-647. https://doi.org/10.1017/iop.2015.93

19. Elfering, A., Pereira, D., Grebner, S., \& Müller, U. (in press). Lack of detachment and impaired sleep connect perceived unfairness with health complaints: A population-based mediation test. Applied Research in Quality of Life. Online first.

20. Etzion, D., Eden, D., \& Lapidot, Y. (1998). Relief from job stressors and burnout: Reserve service as a respite. Journal of Applied Psychology, 83, 577-585. https://doi.org/10.1037/00219010.83.4.577

21. Fredrickson, B. L., Mancuso, R. A., Branigan, C., \& Tugade, M. M. (2000). The undoing effect of positive emotions. Motivation and Emotion, 24, 237-258. https://doi.org/10.1023/A:1010796329158

22. Frese, M. (1985). Stress at work and psychosomatic complaints: A causal interpretation. Journal of Applied Psychology, 70, 314-328. https://doi.org/10.1037/0021-9010.70.2.314

23. Fritz, C., \& Sonnentag, S. (2006). Recovery, well-being, and performance-related outcomes: The role of workload and vacation experiences. Journal of Applied Psychology, 91, 936-945. https:// doi.org/10.1037/0021-9010.91.4.936

24. Gemzøe Mikkelsen, E., \& Einarsen, S. (2002). Relationships between exposure to bullying at work and psychological and psychosomatic health complaints: The role of state negative affectiv- 
ity and generalized self-efficacy. Scandinavian Journal of Psychology, 43, 397-405. https://doi. org/10.1111/1467-9450.00307

25. Gerber, J., \& Wheeler, L. (2009). On being rejected: A meta-analysis of experimental research on rejection. Perspectives on Psychological Science, 4, 468-488. https://doi.org/10.1111/j.17456924.2009.01158.x

26. Geurts, S. A. (2014). Recovery from work during off-job time. In G. F. Bauer \& O. Hämmig (Eds.), Bridging occupational, organizational and public health (pp. 193-208). Dordrecht: Springer. https://doi.org/10.1007/978-94-007-5640-3 12

27. Geurts, S. A., \& Sonnentag, S. (2006). Recovery as an explanatory mechanism in the relation between acute stress reactions and chronic health impairment. Scandinavian Journal of Work, Environment, and Health, 32, 482-492. https://doi.org/10.5271/sjweh.1053

28. Grebner, S., Berlowitz, I., Alvarado, V., \& Cassina, M. (2011). Stress-Studie 2010. Stress bei Schweizer Erwerbstätigen. Zusammenhänge zwischen Arbeitsbedingungen, Personenmerkmalen, Befinden und Gesundheit. Bern: Staatssekretariat für Wirtschaft (Seco).

29. Grebner, S., Semmer, N. K., \& Elfering, A. (2005). Working conditions and three types of well-being: A longitudinal study with self-report and rating data. Journal of Occupational Health Psychology, 10, 31-43. https://doi.org/10.1037/1076-8998.10.1.31

30. Grebner, S., Semmer, N. K., Faso, L. L., Gut, S., Kälin, W., \& Elfering, A. (2003). Working conditions, well-being, and job-related attitudes among call centre agents. European Journal of Work and Organizational Psychology, 12, 341-365. https://doi.org/10.1080/13594320344000192

31. Grossman, P., Niemann, L., Schmidt, S., \& Walach, H. (2004). Mindfulness-based stress reduction and health benefits: A meta-analysis. Journal of Psychosomatic Research, 57, 35-43. https:// doi.org/10.1016/S0022-3999(03)00573-7

32. Gump, B. B., \& Matthews, K. A. (2000). Are vacations good for your health? The 9-year mortality experience after the multiple risk factor intervention trial. Psychosomatic Medicine, 62, 608-612. https://doi.org/10.1097/00006842-200009000-00003

33. Hahn, V. C., Binnewies, C., \& Haun, S. (2012). The role of partners for employees' recovery during the weekend. Journal of Vocational Behavior, 80, 288-298. https://doi.org/10.1016/j. jvb.2011.12.004

34. Hahn, V. C., Binnewies, C., Sonnentag, S., \& Mojza, E. J. (2011). Learning how to recover from job stress: Effects of a recovery training program on recovery, recovery-related self-efficacy, and well-being. Journal of Occupational Health Psychology, 16, 202-216. https://doi.org/10.1037/ a0022169

35. Härmä, M. (2006). Workhours in relation to work stress, recovery and health. Scandinavian Journal of Work, Environment and Health, 32, 502-514. https://doi.org/10.5271/sjweh.1055

36. Härmä, M., Kompier, M. A., \& Vahtera, J. (2006). Work-related stress and health - risks, mechanisms and countermeasures. Scandinavian Journal of Work, Environment and Health, 413-419. https://doi.org/10.5271/sjweh.1047

37. Hobfoll, S. E. (2001). The influence of culture, community, and the nested-self in the stress process: Advancing conservation of resources theory. Applied Psychology: An International Review, 50, 337-421. https://doi.org/10.1111/1464-0597.00062

38. Höge, T. (2009). When work strain transcends psychological boundaries: An inquiry into the relationship between time pressure, irritation, work-family conflict and psychosomatic complaints. Stress and Health, 25, 41-51. https://doi.org/10.1002/smi.1226

39. Jacobson, E. (2011). Entspannung als Therapie: Progressive Relaxation in Theorie und Praxis. Stuttgart: Klett-Cotta.

40. Kabat-Zinn, J. (2003). Mindfulness-based interventions in context: Past, present, and future. Clinical Psychology: Science and Practice, 10, 144-156. https://doi.org/10.1093/clipsy.bpg016

41. Kinnunen, U., Feldt, T., Siltaloppi, M., \& Sonnentag, S. (2011). Job demands-resources model in the context of recovery: Testing recovery experiences as mediators. European Journal of Work and Organizational Psychology, 20, 805-832. https://doi.org/10.1080/1359432X.2010.524411

42. Kinnunen, U., Mauno, S., \& Siltaloppi, M. (2010). Job insecurity, recovery and well-being at work: Recovery experiences as moderators. Economic and Industrial Democracy, 31, 179-194. https:// doi.org/10.1177/0143831X09358366

43. Kivimäki, M., Virtanen, M., Elovainio, M., Kouvonen, A., Väänänen, A., \& Vahtera, J. (2006). Work stress in the etiology of coronary heart disease-a meta-analysis. Scandinavian Journal of Work, Environment and Health, 431-442. https://doi.org/10.5271/sjweh.1049 
44. Klahr, R., Higton, J., \& Harris, T. (2012). Erhebung 2012 über Sicherheit und Gesundheit am Arbeitsplatz in der Schweiz. Bern: Staatssekretariat für Wirtschaft (Seco).

45. Klatt, M. D., Buckworth, J., \& Malarkey, W. B. (2008). Effects of low-dose mindfulness-based stress reduction (MBSR-ld) on working adults. Health Education and Behavior, 36, 601-614. https://doi.org/10.1177/1090198108317627

46. Korstanje, M. E. (2010). The power of projective drawnings: A new method for researching tourist experience. e-Review of Tourism Research, 8(5), 85-101.

47. Korstanje, M. E. (2016). Divorcing after Holidays: From Sacredness to Post-Vacation Blues Syndrome. In N. Pappas, \& I. Bregoli (Eds.), Global Dynamics in Travel, Tourism, and Hospitality (pp. 70-84). Hershey, PA: IGI Global. https://doi.org/10.4018/978-1-5225-0201-2.ch005

48. Korstanje, M., \& Busby, G. (2010). Understanding the Bible as the roots of physical displacement: the origin of tourism. E-Review of Tourism Research, 8(3), 95-111.

49. Krippendorf, Jost. (1987) The Holiday Makers (pp. xiii-xxii). Oxford: Butterworth-Heinemann.

50. Kühnel, J., \& Sonnentag, S. (2011). How long do you benefit from vacation? A closer look at the fade-out of vacation effects. Journal of Organizational Behavior, 32, 125-143. https://doi. org/10.1002/job.699

51. Leary, M. R., Tambor, E. S., Terdal, S. K., \& Downs, D. L. (1995). Self-esteem as an interpersonal monitor: The sociometer hypothesis. Journal of Personality and Social Psychology, 68, 518-530. https://doi.org/10.1037/0022-3514.68.3.518

52. McCallie, M. S., Blum, C. M., \& Hood, C. J. (2006). Progressive muscle relaxation. Journal of Human Behavior in the Social Environment, 13, 51-66. https://doi.org/10.1300/J137v13n03 04

53. McEwen, B. S. (1998). Stress, adaptation, and disease: Allostasis and allostatic load. Annals of the New York Academy of Sciences, 840, 33-44. https://doi.org/10.1111/j.1749-6632.1998. $\underline{\text { tb09546.x }}$

54. Meijman, T. F., \& Mulder, G. (1998). Psychological aspects of workload. In P. J. D. Drenth, H. Thierry, \& C. J. D. Wolff (Eds.), Handbook of work and organizational psychology (pp. 5-33). East Sussex: Psychology Press Ltd.

55. Mohr, G. (1986). Die Erfassung psychischer Befindensbeeinträchtigungen bei Industriearbeitern. Frankfurt am Main: Lang.

56. Muraven, M., \& Baumeister, R. F. (2000). Self-regulation and depletion of limited resources: Does self-control resemble a muscle? Psychological Bulletin, 126, 247-259. https://doi. org/10.1037/0033-2909.126.2.247

57. Nixon, A. E., Mazzola, J. J., Bauer, J., Krueger, J. R., \& Spector, P. E. (2011). Can work make you sick? A meta-analysis of the relationships between job stressors and physical symptoms. Work and Stress, 25, 1-22. https://doi.org/10.1080/02678373.2011.569175

58. Okun, M. L., Kravitz, H. M., Sowers, M. F., Moul, D. E., Buysse, D. J., \& Hall, M. (2009). Psychometric evaluation of the Insomnia Symptom Questionnaire: a self-report measure to identify chronic insomnia. Journal of Clinical Sleep Medicine, 5(1), 41-51.

59. Park, Y., Fritz, C., \& Jex, S. M. (2011). Relationships between work-home segmentation and psychological detachment from work: The role of communication technology use at home. Journal of Occupational Health Psychology, 16, 457-467. https://doi.org/10.1037/a0023594

60. Pereira, D., \& Elfering, A. (2014a). Social stressors at work and sleep during weekends: The mediating role of psychological detachment. Journal of Occupational Health Psychology, 19, 85-95. https://doi.org/10.1037/a0034928

61. Pereira, D., \& Elfering, A. (2014b). Social stressors at work, sleep quality and psychosomatic health complaints - A longitudinal ambulatory field study. Stress and Health, 30, 43-52. https:// doi.org/10.1002/smi.2494

62. Pereira, D., Meier, L. L., \& Elfering, A. (2013). Short-term effects of social exclusion at work and worries on sleep. Stress and Health, 29, 240-252. https://doi.org/10.1002/smi.2461

63. Preacher, K. J., \& Hayes, A. F. (2008). Asymptotic and resampling strategies for assessing and comparing indirect effects in multiple mediator models. Behavior Research Methods, 40, 879891. https://doi.org/10.3758/BRM.40.3.879

64. Ramsey, A. T., \& Jones, E. E. (2015). Minding the interpersonal gap: Mindfulness-based interventions in the prevention of ostracism. Consciousness and Cognition, 31, 24-34. https://doi. org/10.1016/j.concog.2014.10.003

65. Robinson, S. L., O'Reilly, J., \& Wang, W. (2013). Invisible at work: An integrated model of workplace ostracism. Journal of Management, 39, 203-231. https://doi.org/10.1177/0149206312466141 
66. Safstrom, M., \& Hartig, T. (2013). Psychological detachment in the relationship between job stressors and strain. Behavioral Sciences, 3, 418-433. https://doi.org/10.3390/bs3030418

67. Scott, K. D. (2007). The development and test of an exchange-based model of interpersonal workplace exclusion (Doctoral dissertation). Retrieved from University of Kentucky Doctoral Dissertations (Paper 534).

68. Scott, K. D., Restubog, S. L. D., \& Zagenczyk, T. J. (2013). A social exchange-based model of the antecedents of workplace exclusion. Journal of Applied Psychology, 98, 37-48. https://doi. org/10.1037/a0030135

69. Semmer, N.K., Kälin, W., \& Elfering, A. (2008). When time pressure really hurts: The case of performance impairment. 2008 conference of the European Academy of Occupational Health Psychology, Valencia, Spain, 12-14 November 2008.

70. Semmer, N. K., Grebner, S., \& Elfering, A. (2004). Beyond self-report: Using observational, physiological, and event-based measures in research on occupational stress. In P. L. Perrewé \& D. C. Ganster (Eds.), Emotional and physiological processes and positive intervention strategies. Research in Occupational Stress and Well-being, Vol. 3. (pp. 205-263). Amsterdam: JAI.https:/l doi.org/10.1016/S1479-3555(03)03006-3

71. Semmer, N. K., \& Kälin, W. (1999). Skala „Qualitätsbeeinträchtigung durch Zeitdruck“ (unpublished questionnaire). Bern: Universität, Institut für Psychologie.

72. Semmer, N. K., \& Kottwitz, M. U. (2011). Auswirkungen von Freizeit auf Gesundheit und Produktivität - Gutachten zuhanden des Bundesamtes für Justiz. Retrieved from Bundesamt für Justiz: www.bj.admin.ch/dam/data/bj/wirtschaft/gesetzgebung/archiv/ferieninitiative/gutachten-semmer-d.pdf

73. Siltaloppi, M., Kinnunen, U., \& Feldt, T. (2009). Recovery experiences as moderators between psychological work characteristics and occupational well-being. Work and Stress, 23, 330-348. https://doi.org/10.1080/02678370903415572

74. Sluiter, J. K., De Croon, E. M., Meijman, T. F., \& Frings-Dresen, M. H. W. (2003). Need for recovery from work related fatigue and its role in the development and prediction of subjective health complaints. Occupational and Environmental Medicine, 60, i62-i70. https://doi.org/10.1136/ oem.60.suppl_1.i62

75. Sluiter, J. K., Frings-Dresen, M. H. W., van der Beek, A. J., \& Meijman, T. F. (2001). The relation between work-induced neuroendocrine reactivity and recovery, subjective need for recovery, and health status. Journal of Psychosomatic Research, 50, 29-37. https://doi.org/10.1016/S0022$\underline{3999(00) 00213-0}$

76. Sonnentag, S. (2012). Psychological detachment from work during leisure time: The benefits of mentally disengaging from work. Current Directions in Psychological Science, 21, 114-118. https://doi.org/10.1177/0963721411434979

77. Sonnentag, S., \& Bayer, U.-V. (2005). Switching off mentally: Predictors and consequences of psychological detachment from work during off-job time. Journal of Occupational Health Psychology, 10, 393-414. https://doi.org/10.1037/1076-8998.10.4.393

78. Sonnentag, S., \& Fritz, C. (2007). The recovery experience questionnaire: Development and validation of a measure assessing recuperation and unwinding at work. Journal of Occupational Health Psychology, 12, 204-221. https://doi.org/10.1037/1076-8998.12.3.204

79. Sonnentag, S., \& Fritz, C. (2014). Recovery from job stress: The stressor-detachment model as an integrative framework. Journal of Organizational Behavior. Advance online publication. https:// doi.org/10.1002/job.1924

80. Sonnentag, S., \& Jelden, S. (2009). Job stressors and the pursuit of sport activities: A daylevel perspective. Journal of Occupational Health Psychology, 14, 165-https://doi.org/10.1037/ a0014953181.

81. Sonnentag, S., \& Kruel, U. (2006). Psychological detachment from work during off-job time: The role of job stressors, job involvement, and recovery-related self-efficacy. European Journal of Work and Organizational Psychology, 15, 197-217. https://doi.org/10.1080/13594320500513939

82. Sonnentag, S., Kuttler, I., \& Fritz, C. (2010). Job stressors, emotional exhaustion, and need for recovery: A multi-source study on the benefits of psychological detachment. Journal of Vocational Behavior, 76, 355-365. https://doi.org/10.1016/j.jvb.2009.06.005

83. Sonnentag, S., \& Zijlstra, F. R. (2006). Job characteristics and off-job activities as predictors of need for recovery, well-being, and fatigue. Journal of Applied Psychology, 91, 330-350. https:// doi.org/10.1037/0021-9010.91.2.330 
84. Sparks, K., Cooper, C., Fried, Y., \& Shirom, A. (1997). The effects of hours of work on health: A meta-analytic review. Journal of Occupational and Organizational Psychology, 70, 391-408. https://doi.org/10.1111/j.2044-8325.1997.tb00656.x

85. Stansfeld, S., \& Candy, B. (2006). Psychosocial work environment and mental health: A meta-analytic review. Scandinavian Journal of Work, Environment and Health, 443-462. https://doi. org/10.5271/sjweh.1050

86. Strauss-Blasche, G., Ekmekcioglu, C. \& Marktl, W. (2000). Does vacation enable recuperation? Changes in well-being associated with time away from work. Occupational Medicine, 50, 167172. https://doi.org/10.1093/occmed/50.3.167

87. Strauss-Blasche, G., Ekmekcioglu, C. \& Marktl, W. (2002). Moderating effects of vacation on reactions to work and domestic stress. Leisure Sciences, 24, 237-249. https://doi. org/10.1080/01490400252900176

88. Ursin, H., \& Eriksen, H. R. (2004). The cognitive activation theory of stress. Psychoneuroendocrinology, 29, 567-592. https://doi.org/10.1016/S0306-4530(03)00091-X

89. Volmer, J., Binnewies, C., Sonnentag, S., \& Niessen, C. (2012). Do social conflicts with customers at work encroach upon our private lives? A diary study. Journal of Occupational Health Psychology, 17, 304-315. https://doi.org/10.1037/a0028454

90. Westman, M., \& Etzion, D. (2001). The impact of vacation and job stress on burnout and absenteeism. Psychology \& Health, 16, 595-606. https://doi.org/10.1080/08870440108405529

91. Zapf, D., \& Frese, M. (1991). Soziale Stressoren am Arbeitsplatz. In S. Greif, E. Bamberg, \& N. Semmer (Eds.), Psychischer Stress am Arbeitsplatz (pp. 168-184). Göttingen: Hogrefe.

RECIBIDO: 03/02/2016

MODIFICADO: $21 / 11 / 2016$

ACEPTADO: $10 / 01 / 21017$ 